Research Article

\title{
Assessment of Drug Therapy Problems Among Type 2 Diabetes Patients with Hypertension Comorbidity in Indonesia
}

Julaeha ${ }^{*}$ (0)
Ery Fudjiati ${ }^{1}$
Aprilita Rina Yanti Eff 2
1Department of Pharmacy, Universitas
17 Agustus 1945 Jakarta, North Jakarta,
Jakarta Capital Special Region,
Indonesia
2Department of Pharmacy, Universitas
Esa Unggul, West Jakarta, Jakarta
Capital Special Region, Indonesia
*email: julqoz87@gmail.com
Keywords:
Diabetes mellitus
Drug therapy problems
Hypertension
Management therapy
Type 2 Diabetes

\begin{abstract}
Type 2 diabetes mellitus (T2DM) is a major chronic disease that affects a large number of people worldwide. Hypertension is a common disease comorbidity among T2DM patients, and often those patients received polypharmacy and complex treatment in long term duration. This condition may lead to an increased risk of drug therapy problems (DTPs). This study aimed to assess and determine potential drug therapy problems in type 2 diabetic patients with hypertension comorbidity. Retrospective cross-sectional design was conducted in a hospital setting, especially data sources from the prescription of ambulatory T2DM patients with hypertension. A total of 190 patients were studied. More than half of the participants were female $(53.68 \%)$. The majority age range of participants was $50-59$ years $(46.84 \%)$. Almost all antidiabetic agents were prescribed as polypharmacy (73.16\%). Metformin was the most antidiabetic agent prescribed as monotherapy and combination therapy (63.16\%). Almost all antihypertensive agents were prescribed as polypharmacy $(63.26 \%)$. Amlodipine was the most antihypertensive agent prescribed as monotherapy and combination therapy (34.74\%). Among the study participants, $56.84 \%$ have at least one of DTPs. Adverse drug reaction was the most frequent $(47.22 \%)$, followed by ineffective drug therapy $(29.63 \%)$. Since the potential of DTPs in T2DM patients with hypertension comorbidity is relatively high, early identifying, resolving, and preventing drug therapy problems by the pharmacist is needed to achieve goals of treatment.
\end{abstract}

Received: April 21st, 2020

Accepted: July 1st, 2020

Published: August 1st, 2020

(C) 2020 Julaeha, Ery Fudjiati, Aprilita Rina Yanti Eff. Published by Institute for Research and Community Services Universitas Muhammadiyah Palangkaraya. This is an Open Access article under the CC-BY-SA License (http://creativecommons.org/licenses/by-sa/4.0/). DOI: https://doi.org/10.33084/bjop.v3i3.1359

\section{INTRODUCTION}

Diabetes Mellitus (DM) has become a popular chronic disease worldwide. The prevalence of DM is $8.8 \%$ globally and $8.6 \%$ in Southeast Asia. It has been increasing rapidly in low- and middle-income countries (Dunning et al., 2014). Based on a national survey, in the year 2030 number of DM cases Indonesia estimated about 21.3 million (Ministry of Health of the Republic of Indonesia, 2018).

Uncontrolled DM treatment is a serious problem that might be caused by microvascular and macrovascular complications (Chawla et al., 2016; Cade, 2008) and death (American Diabetes Association, 2015). Cardiovascular disease (CVD) is the leading cause of death in patients with diabetes mellitus (Benjamin et al., 2017). Health problems in many developing countries are in epidemiology transition where chronic NonCommunicable Diseases (NDCs) are major public health concerns due to the enormous financial burden associated with these diseases. Diabetes mellitus and hypertension were top the list of NDCs, these two chronic diseases are the most important risk factor for cardiovascular diseases (Bolarinwa et al., 2018). 
Hypertension is the most common disease comorbidity with diabetes. The presence of hypertension with diabetes increases in mortality and drug therapy problems worldwide, with a greater risk in developing countries (Petrie et al., 2018; James et al., 2014). Hypertension and type 2 diabetes mellitus (T2DM) called "lethal duo" which increases the risk of cardiovascular disease 2-to 4-fold over both diseases themselves, such as heart attack, stroke, ischemic heart disease, and microvascular complications (Farský et al., 2018).

Multiple medical conditions have been shown to contribute to drug therapy problems (DTPs) (Gangwar et al., 2014). Similarly, T2DM patients with hypertension often use polypharmacy medication and this may lead to the occurrence of drug therapy problems. Studies show that the number of DTPs per patient linearly increases with the increase in the number of medicines used (Abdulmalik et al., 2019).

Several studies in some countries such as Malaysia, Ethiopia, and Nigeria about DTPs in T2DM with hypertension have shown that each diabetes patients experienced at least one of drug therapy problems (Huri \& Wee, 2013; Yimama et al., 2018; Argaw et al., 2019; Hussen \& Daba, 2017; Ayele et al., 2018; Ogbonna et al., 2014). Drug therapy problems may lead to elevating morbidity, disability, mortality, health care cost, low adherence, and prolonged hospitalization (Nivya et al., 2015; Claydon-Platt et al., 2012).

In Indonesia, hypertension is a common comorbidity in T2DM patients. However, Indonesia has no adequate and comprehensive studies on DTPs, particularly among T2DM patients with hypertension comorbidity. The aims of this study are to determine pattern prescription of antidiabetic and antihypertensive agents, to assess the prevalence of potential drug therapy problems, and to identify determine of drug therapy problems among T2DM patients with hypertension comorbidity.

\section{MATERIALS AND METHODS}

This is a retrospective cross-sectional study design that was conducted in the inpatient ward of secondary care hospital in West Java Indonesia. This study has approval by the Awal Bros Hospital Bekasi Barat education and ethics committee No. 100/DIR/RSAB-BKS/1/2015. A total of 190 patients who admitted to the hospital from January until December 2014 and meet the inclusion criteria. The inclusion criteria were:

1. Adult patient ( $\geq 40$ years old)

2. Diagnosed T2DM with hypertension comorbidity

3. Prescribed at least one antidiabetic agent and antihypertensive agent

The exclusion criteria are patients with the pregnant condition. Data collected from the medical record and the prescriptions of T2DM with hypertension comorbidity. The identified of DTPs was classified based on pharmaceutical care practice the third edition were:

1. Unnecessary drug therapy

2. Need additional drug therapy

3. Ineffective drug therapy

4. Dosage too low

5. Dosage too high

6. Adverse drug reaction

7. Non-adherence/non-compliance (Cipolle et al., 2012). This study was performed a descriptive analysis of demographic characteristics, pattern prescriptions antidiabetic and antihypertensive agents, as well as type and cause of DTPs.

\section{RESULTS AND DISCUSSION}

\section{Demographic characteristics}

As many as 190 patients included in this study. More than half of the patients were female $(53.68 \%)$. The age range of the majority of patients was 50-59 years (46.84\%), followed by $60-69$ years (30.53\%), $40-49$ years (12.10\%), $70-79$ years $(8.95 \%)$, and more than 80 years $(1.58 \%)$. 
These results were in the line with Zazuli et al. (2017) and Ayele et al. (2018) who reported majority T2DM patients with hypertension comorbidity were female and age range under 56 years old. Contrasting to Yimama et al. (2018) and Argaw et al. (2019) who reported that majority T2DM patients and hypertension comorbidity were males. This result pointed risk of hypertension disease in T2DM patients equally between each gender.

Prescription patterns of antidiabetic and antihypertensive agents

Among the participants, only $26.84 \%$ received monotherapy antidiabetic. Of the total participants, $73.16 \%$ received between two until five antidiabetic agents. Metformin (63.16\%) followed by glimepiride $(46.84 \%)$ were the most frequently antidiabetic agents prescribed as monotherapy and combination with other antidiabetic agents, as presented in Table I. This result supported by Yimama et al. (2018), Argaw et al. (2019), Ayele et al. (2018), and Ogbonna et al. (2014) who reported metformin as the most antidiabetic agent prescribed for monotherapy or combination. This study contrasts with Zazuli et al. (2017) who reported insulin was the most prescribed as monotherapy and combination. Polypharmacy antidiabetic prescriptions are one of the factors identified to influence non-adherence in T2DM patients with hypertension (Atinga et al., 2018).

Table I. Patterns prescription of antidiabetic agents in T2DM with hypertension $(\mathrm{n}=190)$

\begin{tabular}{ll}
\hline \multicolumn{1}{c}{ Variable category } & \multicolumn{1}{c}{$\mathbf{N ~ ( \% )}$} \\
\hline Number of prescription & \\
\hline Monotherapy & $51(26.84)$ \\
2 antidiabetic agents & $90(47.37)$ \\
3 antidiabetic agents & $35(18.42)$ \\
4 antidiabetic agents & $10(5.26)$ \\
5 antidiabetic agents & $4(2.11)$ \\
\hline Type of antidiabetic agents & \\
\hline Metformin* & $120(63.16)$ \\
Glibenclamide & $10(5.26)$ \\
gliquidone & $31(16.32)$ \\
Glimepiride* & $89(46.84)$ \\
Pioglitazone & $2(1.05)$ \\
Acarbose & $7(3.68)$ \\
Linagliptine & $36(18.95)$ \\
Sitagliptine & $43(22.63)$ \\
Vidagliptine & $14(7.37)$ \\
Insulin & $15(7.89)$ \\
\hline
\end{tabular}

\begin{tabular}{ll}
\hline Combined antidiabetic agents & \\
\hline Acarbose + Glimepiride & $2(1.05)$ \\
Acarbose + Glimepiride + Linaglibtin & $1(0.53)$ \\
Acarbose + Glimepiride + Metformin & $2(1.05)$ \\
Gliquidone + Glimepiride + Metformin + & $1(0.53)$ \\
Linaglibtin & \\
Gliquidone + Linaglibtin & $2(1.05)$ \\
Gliquidone + Sitaglipin & $2(1.05)$ \\
Gliquidone + Metformin + Linaglibtin & $4(2.11)$ \\
Gliquidone + Metformin + Linaglibtin + & $4(2.11)$ \\
Sitaglipin + Vidaglibtin & \\
Glimepiride + Metformin + Linaglibtin & $6(3.16)$ \\
Glimepiride + Metformin + Sitaglipin & $8(4.21)$ \\
Glimepiride + Metformin + Vidaglibtin + & $4(2.11)$ \\
Sitaglipin & \\
Glimepiride + Metformin + Linaglibtin + & $4(2.11)$ \\
Sitaglipin & \\
Glimepiride + Linaglibtin & $5(2.63)$ \\
Glimepiride + Sitaglipin & $2(1.05)$ \\
Glimepiride + Pioglitazon & $1(0.53)$ \\
Metformin + Glibenklamid & $4(2.11)$ \\
Metformin + Glimenklamid + Glimepiride & $4(2.11)$ \\
Metformin + Gliquidone & $6(3.16)$ \\
Metformin + Gliquidone + Glimepiride & $6(3.16)$ \\
Metformin + Glimepiride & $37(19.47)$ \\
Metformin + Linaglibtin & $6(3.16)$ \\
Metformin + Sitaglipin & $10(5.26)$ \\
Metformin + Vidaglibtin & $4(2.11)$ \\
Insulin + Acarbose & $1(0.53)$ \\
Insulin + Gliquidone & $3(1.68)$ \\
Insulin + Gliquidone + Linaglibtin & $1(0.53)$ \\
Insulin + Glimepiride + Metformin & $2(1.05)$ \\
Insulin + Glimepiride + Metformin + & $1(0.53)$ \\
Sitaglipin & \\
Insulin + Metformin & $5(2.63)$ \\
Insulin + Metformin + Sitaglipin & $1(0.53)$ \\
*Themost prescribed antidiabetic agents & \\
& \\
&
\end{tabular}

Hypertension is a common comorbidity in diabetic patients, and adequate blood pressure control significantly reduces the risk of macrovascular and microvascular complications. More than half of the participants $(63.26 \%)$ received more than one antihypertensive agent. This study is in line with Hussen et al. (2017) who reported more than half of patients $(62.7 \%)$ received a combination of two or more antihypertensive drugs. Amlodipine (34.74\%) followed by furosemide $(17.90 \%)$, candesartan $(16.84 \%)$, captopril (13.68\%), and bisoprolol (12.63\%) were the five most prescribed antihypertensive agents, as shown in Table II. This result is supported by Zazuli et al. (2017) who reported amlodipine to be the most prescribed antihypertensive agent in diabetic patients with hypertension. However, these results contradict with study by Yimama et al. (2018), Argaw et al. (2019), and 
Ayele et al. (2018) who reported enalapril as the most commonly prescribed antihypertensive drug. This study also contrasts with Hussen et al. (2017) who reported the most commonly prescribed antihypertensive medication was hydrochlorothiazide (41.4\%). These results confirm that country differences play a very important role in the most prescribed type of antihypertensive agents.

The target blood pressure in T2DM with hypertension is 130/80 mmHg. Initial treatment for T2DM patients depends on the severity of hypertension. Those who have blood pressure between 140/90 to 159/99 mmHg should start with monotherapy. Angiotensin-converting enzyme (ACE) inhibitors or Angiotensin II receptor blockers (ARB) are recommended as initial treatment in diabetic patients with hypertension. For patients with blood pressure $\geq 160 / 100 \mathrm{mmHg}$, initial therapy with two antihypertensives is recommended. However, the use of both ACE inhibitors and ARBs in combination is not recommended due to increased side effects such as hyperkalemia, syncope, and acute kidney injury (de Boer et al., 2017). The combination of ACE inhibitors or ARBs with calcium-channel blockers (CCBs) is preferred for nephroprotective, angioprotective, and metabolic effects. This drug is used for normotensive T2DM patients for albuminuria, retinopathy, and stroke prevention (Farský et al., 2018).

Table II. Patterns prescription of antihypertensive agents in T2DM with hypertension $(\mathrm{n}=190)$

\begin{tabular}{ll}
\hline \multicolumn{1}{c}{ Variable category } & \multicolumn{1}{c}{$\mathbf{N ~ ( \% )}$} \\
\hline Number of prescription & \\
\hline Monotherapy & $85(44.74)$ \\
2 anti-hypertension agents & $71(37.37)$ \\
3 anti-hypertension agents & $22(11.58)$ \\
4 anti-hypertension agents & $10(5.26)$ \\
5 anti-hypertension agents & $2(1.05)$ \\
\hline Type of antihypertensive agents $^{\text {Captopril }}{ }^{*}$ & \\
\hline Ramipril $_{\text {Candesartan }}^{*}$ & $26(13.68)$ \\
Irbesartan $_{\text {Telmisartan }}$ & $3(1.58)$ \\
Valsartan $_{\text {Furosemide }}^{*}$ & $32(16.84)$ \\
Bisoprolol $^{*}$ & $8(4.21)$ \\
Amlodipine & $8(4.21)$ \\
Diltiazem $^{*}$ & $5(2.63)$ \\
\hline
\end{tabular}

\begin{tabular}{|c|c|}
\hline Atenolol & $1(0.53)$ \\
\hline Carvedilol & $6(3.16)$ \\
\hline Hydrochlorothiazide & $1(0.53)$ \\
\hline Losartan & $1(0.53)$ \\
\hline Spironolakton & $6(3.16)$ \\
\hline & $6(3.16)$ \\
\hline $\begin{array}{l}\text { Nifedipin } \\
\text { Popranolol }\end{array}$ & $1(0.53)$ \\
\hline \multicolumn{2}{|l|}{ Combined antihypertensive agents } \\
\hline Amlodipine + Atenolol & $1(0.53)$ \\
\hline Amlodipine + bisoprolol & $9(4.74)$ \\
\hline Amlodipine + Bisoprolol + Furosemida & $1(0.53)$ \\
\hline \multicolumn{2}{|c|}{ Amlodipin + Bisoprolol + Irbesartan $+2(1.05)$} \\
\hline \multicolumn{2}{|c|}{$\begin{array}{l}\text { Amlodipin }+ \text { Bisoprolol }+ \text { Candesartan }+1(0.53) \\
\text { Ramipril }\end{array}$} \\
\hline Amlodipin + Bisoprolol + Captopril & $2(1.05)$ \\
\hline Amlodipin + Furosemida Injection & $4(2.11)$ \\
\hline Amlodipin + Furosemida & $2(1.05)$ \\
\hline Amlodipin + Irbesartan & $6(3.16)$ \\
\hline Amlodipin + Candesartan & $8(4.21)$ \\
\hline Amlodipin + Irbesartan + Spironolakton & $1(0.53)$ \\
\hline Amlodipin + Candesartan + Bisoprolol & $1(0.53)$ \\
\hline Amlodipin + Candesartan + Furosemida & $1(0.53)$ \\
\hline Amlodipin + Captopril & $11(5.79)$ \\
\hline Amlodipin + Captopril + Furosemid & $1(0.53)$ \\
\hline Amlodipin + Captopril + Losartan & $1(0.53)$ \\
\hline Amlodipin + Captopril + Nifedipin & $1(0.53)$ \\
\hline Amlodipin + Carvedilol + Furosemid & $1(0.53)$ \\
\hline Amlodipin + Propranolol & $1(0.53)$ \\
\hline $\begin{array}{l}\text { Amlodipin }+ \text { Telmisartan }+ \text { Furosemid } \\
\text { Injection }\end{array}$ & $1(0.53)$ \\
\hline Amlodipin + Valsartan & $3(1.58)$ \\
\hline Bisoprolol + Diltiazem & $1(0.53)$ \\
\hline Bisoprolol + Furosemid Injection & $3(1.58)$ \\
\hline $\begin{array}{l}\text { Bisoprolol }+ \text { Furosemida } \text { Injection }+ \\
\text { Telmisartan }\end{array}$ & $2(1.05)$ \\
\hline Bisoprolol + Irbesartan & $1(0.53)$ \\
\hline Bisoprolol + Candesartan & $1(0.53)$ \\
\hline Bisoprolol + Candesartan + Furosemida & $1(0.53)$ \\
\hline $\begin{array}{l}\text { Bisoprolol + Candesartan }+ \text { Furosemida }+ \\
\text { Furosemida Injection }\end{array}$ & $1(0.53)$ \\
\hline $\begin{array}{l}\text { Bisoprolol }+ \text { Candesartan }+ \text { Furosemida }+ \\
\text { Spironolakton }\end{array}$ & $1(0.53)$ \\
\hline $\begin{array}{l}\text { Bisoprolol + Carvedilol + Candesartan + } \\
\text { Furosemida + Furosemida Injection }\end{array}$ & $1(0.53)$ \\
\hline Bisoprolol + Candesartan + Nifedipine & $1(0.53)$ \\
\hline Bisoprolol + Captopril & $5(2.63)$ \\
\hline Bisoprolol + Captopril + Furosemida Injection & $1(0.53)$ \\
\hline Bisoprolol + Captopril + Nifedipine & $2(1.05)$ \\
\hline $\begin{array}{l}\text { Bisoprolol }+ \text { Captopril }+ \text { Nifedipine }+ \\
\text { Irbesartan }+ \text { Diltiazem }\end{array}$ & $1(0.53)$ \\
\hline Bisoprolol + Ramipril & $1(0.53)$ \\
\hline Bisoprolol + Telmisartan & $1(0.53)$ \\
\hline $\begin{array}{l}\text { Furosemida injection }+ \text { Furosemida }+ \\
\text { Carvedilol }+ \text { Spironolakton }\end{array}$ & $1(0.53)$ \\
\hline Furosemida injection + Captopril & $1(0.53)$ \\
\hline Furosemida injection + Telmisartan & $1(0.53)$ \\
\hline Furosemida + Candesartan & $1(0.53)$ \\
\hline Furosemida + Spironolakton + Carvedilol & $1(0.53)$ \\
\hline Irbesartan + Nifedipin & $1(0.53)$ \\
\hline Candesartan + Furosemida injection & $2(1.05)$ \\
\hline $\begin{array}{l}\text { Candesartan }+ \text { Furosemida }+ \text { Furosemida } \\
\text { injection }\end{array}$ & $1(0.53)$ \\
\hline Candesartan + Captopril & $2(1.05)$ \\
\hline Candesartan + Nifedipine & $1(0.53)$ \\
\hline $\begin{array}{l}\text { Candesartan + Valsartan + Furosemida + } \\
\text { Spironolakton }\end{array}$ & $2(1.05)$ \\
\hline Captopril + Furosemida innjection & $1(0.53)$ \\
\hline Captopril + Irbesartan + Furosemida injection & $1(0.53)$ \\
\hline Captopril + Telmisartan + Furosemida & $1(0.53)$ \\
\hline
\end{tabular}




\begin{tabular}{ll}
\hline Captopril + Nifedipine & $1(0.53)$ \\
Ramipril + Furosemida injection & $1(0.53)$ \\
Furosemida + Spironolakton & $1(0.53)$ \\
Telmisartan + Carvedilol + Furosemida + & $1(0.53)$ \\
Furosemida injection & \\
Valsartan + Hydrochlorothiazide & $1(0.53)$ \\
Valsartan + Carvedilol & $1(0.53)$ \\
\hline${ }^{*}$ Themost prescribed antihypertensive agents
\end{tabular}

Treatment of diabetes with comorbid hypertension in COVID-19

At present, in the condition of the pandemic novel coronavirus 2019 (COVID-19), diabetic comorbidities are one of the risk factors for hospitalization and death due to COVID-19. Diabetes was a comorbidity in $22 \%$ of nonsurvivors in a study of 52 intensive care patients (Yang et al., 2020). Other comorbidities such as hypertension in about $20 \%$ of cases, cardiovascular disease $(16 \%)$, and lung disease $(6 \%)$ are other common comorbidities (Ruan et al., 2020; Wu et al., 2020; Li et al., 2020). In fact, patients with T2DM are at high risk for infection and suffer severe symptoms of COVID-19, including bacterial pneumonia which can be reduced through good blood glucose control (Critchley et al., 2018). Basalbolus insulin or insulin pump therapy will be preferred in T2DM patients to avoid hyperglycemia and ketoacidosis. It also requires monitoring of blood glucose levels and setting insulin doses to prevent hypoglycemia (Apicella et al., 2020).

The other most common comorbidities in COVID-19 patients besides diabetes are hypertension. Both of these diseases are often treated with ACE inhibitors and ARBs. COVID-19 binds to target cells via angiotensinconverting enzyme 2 (ACE2) expressed in epithelial cells in the lungs, blood vessels, and in the intestine (Wan et al., 2020). Patients treated with ACE inhibitors and ARBs showed an increase in the number of ACE2 (Li et al., 2017). Therefore, there are two hypothetical drugs of choice in comorbid hypertension in COVID-19 infections. Hypothesis by Fang et al. (2020) suggests that COVID-19 patients with hypertension, diabetes, and cardiovascular disease treated with ACE inhibitors and
ARBs should monitor ACE2 counts or consider other antihypertensives, CCBs as therapies that are known to not increase the amount of ACE2 expressed and their activities because it can be an appropriate alternative depending on the patient's condition. Another hypothesis by Singh et al. (2020) emphasize because of the lack of evidence for the benefits or dangers of using $\mathrm{ACE}$ inhibitors and ARBs in patients with diabetes and hypertension with COVID-19, it makes sense for patients to continue using both. This is the following recommendation by the European Society of Cardiology, Hypertension Canada, The Canadian Cardiovascular Society, the UK Renal Association, the International Society of Hypertension, the European Society of Hypertension, and the American Heart Association.

\section{Drug therapy problems}

Among the participants, more than half of the participants (56.84\%) have at least one of DTPs. The number of DTPs finding is lower than Yimama et al. (2018) and Shareef et al. (2015), where $82 \%$ and $71.1 \%$ of participants at least had one of DTPs, respectively. A total of 108 DTPs was identified across the six categories as presented in Table III. Adverse drug reaction was the highest 51 cases (47.22\%), followed by ineffective drug therapy 32 cases $(29.63 \%)$, unnecessary drug therapy 19 cases $(17.6 \%)$, as well as need additional therapy, dose too low, and dose too high, each of them with two cases $(1.85 \%)$. These study findings supported by Nazilah et al. (2017), Lira et al. (2017), and Hartuti et al. (2019), which highlighted adverse drug reaction and drug interaction as most common DTPs occurred during polypharmacy treatment prescribed. Potential adverse drug reaction event in the combination of medications treatment higher than single medication treatment. This study contrasting to another study who reported the most common drug therapy problems was the need for additional drug therapy (Yimama et al., 2018; Argaw et al., 2019; Hussen et 
al., 2017). Percentage of DTP events in this study is visualized in Figure 1.

Table III. Causes of DTPs among T2DM with hypertension in hospital setting $(n=108)$

\begin{tabular}{|c|c|c|}
\hline Category of DTPs & Causes of DTPS & Frequency (\%) \\
\hline Adverse drug & Drug interaction & $32(29.63)$ \\
\hline reaction & Contraindication & 19 (17.59) \\
\hline $\begin{array}{l}\text { Ineffective drug } \\
\text { therapy }\end{array}$ & $\begin{array}{l}\text { Not the most } \\
\text { effective for }\end{array}$ & $32(29.63)$ \\
\hline $\begin{array}{l}\text { Unnecessary drug } \\
\text { therapy }\end{array}$ & $\begin{array}{l}\text { medical problem } \\
\text { Not valid medical } \\
\text { indication for the } \\
\text { drug therapy at } \\
\text { this time }\end{array}$ & $19(17.60)$ \\
\hline $\begin{array}{l}\text { Need additional } \\
\text { therapy }\end{array}$ & $\begin{array}{l}\text { To attain } \\
\text { synergistic/ } \\
\text { additive effect }\end{array}$ & $2(1.85)$ \\
\hline Dosage too low & $\begin{array}{l}\text { Dosage regime not } \\
\text { frequent enough }\end{array}$ & $2(1.85)$ \\
\hline Dosage too high & $\begin{array}{l}\text { Dosage regime too } \\
\text { frequent }\end{array}$ & $2(1.85)$ \\
\hline
\end{tabular}

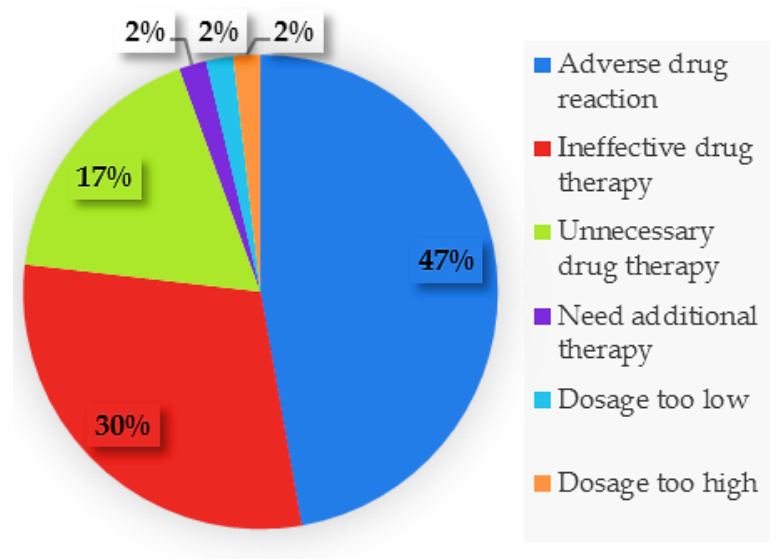

Figure 1. Percentage of DTP events

Among these DTPs, adverse drug reactions were the most common DTP category (47.22\%). The possible causes of this DTPs were drug interaction (29.63\%) and contraindications (17.59\%). Potential drug interactions include antidiabetic and antibiotic, antihypertensive and antifungal, and fellow antihypertensive. Drug interactions may occur in the pharmacokinetic phase caused by inhibitory metabolic mechanisms. Possible side effects are an increased risk of heart blockage and an increased effect of hypoglycemia (Baxter, 2009). The possible drug interactions that occur are presented in

Table IV.
Table IV. Determinant of drug-drug interaction in T2DM patients with hypertension $(n=32)$

\begin{tabular}{|c|c|c|c|}
\hline $\begin{array}{l}\text { Drug-drug } \\
\text { interaction }\end{array}$ & Mechanism & Category & $\mathbf{N}$ \\
\hline $\begin{array}{l}\text { Glimepiride- } \\
\text { Levofloxacin/ } \\
\text { Moxifloxacin }\end{array}$ & $\begin{array}{l}\text { Potential to } \\
\text { elevate } \\
\text { hypoglycemia } \\
\text { effect }\end{array}$ & Pharmacokinetics & 12 \\
\hline $\begin{array}{l}\text { Amlodipine- } \\
\text { Fluconazole }\end{array}$ & $\begin{array}{l}\text { Decrease } \\
\text { amlodipine } \\
\text { metabolism, } \\
\text { might be } \\
\text { increase risk of } \\
\text { heart block }\end{array}$ & Pharmacokinetics & 3 \\
\hline $\begin{array}{l}\text { Atenolol- } \\
\text { Amlodipine }\end{array}$ & $\begin{array}{l}\text { Increase risk of } \\
\text { heart block }\end{array}$ & Pharmacokinetics & 1 \\
\hline $\begin{array}{l}\text { Bisoprolol- } \\
\text { Diltiazem }\end{array}$ & $\begin{array}{l}\text { Increase risk of } \\
\text { heat block }\end{array}$ & Pharmacokinetics & 1 \\
\hline $\begin{array}{l}\text { Bisoprolol- } \\
\text { Nifedipine }\end{array}$ & $\begin{array}{l}\text { Increase risk of } \\
\text { heart block }\end{array}$ & Pharmacokinetics & 2 \\
\hline $\begin{array}{l}\text { Bisoprolol- } \\
\text { Insulin }\end{array}$ & $\begin{array}{l}\text { Potential to } \\
\text { elevate } \\
\text { hypoglycemia } \\
\text { effect }\end{array}$ & Pharmacokinetics & 3 \\
\hline $\begin{array}{l}\text { Ramipril- } \\
\text { Spironolacton }\end{array}$ & $\begin{array}{l}\text { Potential to } \\
\text { elevate } \\
\text { hypoglycemia } \\
\text { effect }\end{array}$ & Pharmacokinetics & 1 \\
\hline $\begin{array}{l}\text { Bisoprolol- } \\
\text { Amlodipine }\end{array}$ & $\begin{array}{l}\text { Increase risk of } \\
\text { heart block }\end{array}$ & Pharmacokinetics & 9 \\
\hline
\end{tabular}

In this study, ineffective drug therapy (29.63\%) and unnecessary drug therapy $(17.60 \%)$ were the second and third most potential DTPs, respectively. Ineffective drug therapy was found in 32 T2DM patients with hypertension who received furosemide because the antihypertensive treatment might be involved in glucose tolerance. Meanwhile, the drug of choice for hypertension with diabetes based on guidelines recommends the use of ACE inhibitors or ARBs or nondihydropyridine CCBs (James et al., 2014). Unnecessary drug therapy in 10 patients who received antibiotics and nine patients received gastrointestinal drugs without clear indications. Need additional therapy, the dose is too low, and the dose is too high, each only $1.85 \%$ of the total DTPs. This insignificant amount might be due to the study being conducted in patients who were hospitalized, where there are better care and collaboration of health professionals with supervised drug administration. Because of the retrospective data 
source in this study, non-compliance with treatment was excluded to be assessed in this study.

There are several limitations to this study. First, this study is not from an evaluation of prospective structures or interviews with patients. Second, this study did not assess treatment compliance among T2DM patients with hypertension. However, this study has several advantages, including this research which is a pioneer in the study of DTPs assessment in T2DM patients with hypertension. Besides, this study proposes insights for the drug of choice in T2DM patients and hypertension who are infected with COVID-19.

\section{CONCLUSION}

This study highlights the majority of T2DM patients with comorbid hypertension who have at least one drug therapy problem that might have an impact on treatment goals and treatment costs. The role of pharmacists in drug management by detecting, preventing, and solving drug therapy problems can be encouraged to deal with these problems.

\section{ACKNOWLEDGMENT}

We acknowledge the head and all staffs of the Awal Bros Hospital for providing support and facilitating the data collection.

\section{REFERENCES}

Abdulmalik, H., Tadiwos, Y., \& Legese, N. (2019). Assessment of drug-related problems among type 2 diabetic patients on follow up at Hiwot Fana Specialized University Hospital, Harar, Eastern Ethiopia. BMC Research Notes, 12(771), 16. doi:10.1186/s13104-019-4760-8

American Diabetes Association. (2015). Standards of Medical Care in Diabetes-2015: Summary of Revisions. Diabetes Care, 38(Supplement 1), S4 S4. doi:10.2337/dc15-S003
Apicella, M., Campopiano, M.C., Mantuano, M., Mazoni, L., Coppelli, A., \& Prato, S.D. (2020). COVID19 in people with diabetes: understanding the reasons for worse outcomes. The Lancet Diabetes $\mathcal{E}$ Endocrinology, [Epub ahead of print]. doi:10.1016/S2213-8587(20)30238-2

Argaw, A.M., Hiwet, T.T.G., \& Derse, B.B. (2019). Drug Therapy Problems and Determinants among Ambulatory Type 2 Diabetes Mellitus Patients: Pharmacists' Intervention in South-East Ethiopia. Endocrinology \& Metabolic Syndrome, 8(4), 303. doi:10.35248/2161-1017.19.8.303

Atinga, R.A., Yarney, L., \& Gavu, N.M. (2018). Factors influencing long-term medication nonadherence among diabetes and hypertensive patients in Ghana: A qualitative investigation. PLoS One, 13(3), e0193995. doi:10.1371/journal.pone.0193995

Ayele, Y., Melaku, K., Dechasa, M., Ayalew, M.B., \& Horsa, B.A. (2018). Assessment of drug related problems among type 2 diabetes mellitus patients with hypertension in Hiwot Fana Specialized University Hospital, Harar, Eastern Ethiopia. BMC Research Notes, 11(1), 728. doi:10.1186/s13104-018-3838-z

Baxter, K. (2009). Stockley's Drug Interactions 2009 - Pocket Companion. London, United Kingdom: Pharmaceutical Press.

Benjamin, E.J., Blaha, M.J., Chive, S.E., Cushman, M., Das, S.R., Deo, R., de Ferranti, S.D., Floyd, J., Fornage, M., Gillespie, C., Isasi, C.R., Jiménez, M.C., Jordan, L.C., Judd, S.E., Lackland, D., Lichtman, J.H., Lisabeth, L., Liu, S., Longenecker, C.T., Mackey, R.H., Matsushita, K., Mozaffarian, D., Mussolino, M.E., Nasir, K., Neumar, R.W., Palaniappan, L., Pandey, D.K., Thiagarajan, R.R., Reeves, M.J., Ritchey, M., Rodriguez, C.J., Roth, G.A., Rosamond, W.D., Sasson, C., Towfighi, A., Tsao, C.W., Turner, M.B., Virani, S.S., Voeks, J.H., Willey, J.Z., Wilkins, J.T., Wu, J.H.Y., Alger, H.M., Wong, S.S., \& Muntner, P. (2017). Heart Disease and Stroke Statistics - 2017 Update: A Report from the American Heart Association. Circulation, 135(10), e146-e603. doi:10.1161/CIR.0000000000000485

de Boer, I.H., Bangalore, S., Benetos, A., Davis, A.M., Michos, E.D., Muntner, P., Rossing, P., Zoungas, S., \& Bakris, G. (2017). Diabetes and Hypertension: A Position Statement by the 
American Diabetes Association. Diabetes Care, 40(9), 1273-1284. doi:10.2337/dci17-0026

Bolarinwa, O.A., Abdulahi, A., Sanya, E.O., Kolo, P.M., Ameen, H.A., Durowade, K.A., Uthman, M.M.B., Ogunmodede, J.A., Buliaminu, S.A., Odeigah, L.O., \& Akande, T.M. (2018). Predictors of Cost of Follow-up Care among Patients with Hypertension and Diabetes Mellitus Attending a Teaching Hospital, North Central, Nigeria. Journal of Health Science Research, 3(2), $1-9$. doi:10.18311/jhsr/2018/21335

Cade, W.T. (2008). Diabetes-Related Microvascular and Macrovascular Diseases in the Physical Therapy Setting. Physical Therapy, 88(11), 13221335. doi:10.2522/ptj.20080008

Chawla, A., Chawla, R., \& Jaggi, S. (2016). Microvascular and macrovascular complications in diabetes mellitus: Distinct or continuum? Indian Journal of Endocrinology and Metabolism, 20(4), 546-551. doi:10.4103/2230-8210.183480

Cipolle, R.J., Strand, L.M., \& Morley, P.C. (2012). Pharmacentical Care Practice: The PatientCentered Approach to Medication Management Services, third edition. New York, United States: McGraw-Hill Education, LLC.

Claydon-Platt, K., Manias, E., \& Dunning, T. (2012). Medication-related problems occurring in people with diabetes during an admission to an adult teaching hospital: a retrospective cohort study. Diabetes Research and Clinical Practice, $\quad$ 97(2), 223-230. doi:10.1016/j.diabres.2012.03.003

Critchley, J.A., Carey, I.M., Harris, T., DeWilde, S., Hosking, F.J., \& Cook, D.G. (2018). Glycemic Control and Risk of Infections Among People with Type 1 or Type 2 Diabetes in a Large Primary Care Cohort Study. Diabetes Care, 41(10), 2127-2135. doi:10.2337/dc18-0287

Dunning, T., Sinclair, A., \& Colagiuri, S. (2014). New IDF Guideline for managing type 2 diabetes in older people. Diabetes Research and Clinical Practice, 103(3), 538-540. doi:10.1016/j.diabres.2014.03.005

Fang, L., Karakiulakis, G., \& Roth, M. (2020). Are patients with hypertension and diabetes mellitus at increased risk for COVID-19 infection? The
Lancet Respiratory Medicine, 8(4), e21. doi:10.1016/S2213-2600(20)30116-8

Farský, Š., Strišková, A., \& Borčin, M. (2018). Hypertension Treatment in Patients with Metabolic Syndrome and/or Type 2 Diabetes Mellitus: Analysis of the Therapy Effectivity and the Therapeutic Inertia in Outpatient Study. Cardiology Research and Practice, 2018, 8387613. doi:10.1155/2018/8387613

Gangwar, S.S., Monisha, N., Nachiya, J., Narasingarao, K., Parimalakrishnan, S., \& Singh, S.P. (2014). Impact of medication and psychological behaviour assessment by community pharmacists in type 2 diabetes mellitus patients after hospital stay. African Health Sciences, 14(3), 539-550. doi:10.4314/ahs.v14i3.7

Hartuti, S., Nasution, A., \& Syafril, S. (2019). The Effect of Drug-Related Problems on Blood Glucose Level in the Treatment of Patients with Type 2 Diabetes Mellitus. Open Access Macedonian Journal of Medical Sciences, 7(11), 1798-1802. doi:10.3889/oamims.2019.290

Huri, H.Z. \& Wee, H.F. (2013). Drug related problems in type 2 diabetes patients with hypertension: a cross-sectional retrospective study. BMC Endocrine Disorders, 13, 2. doi:10.1186/14726823-13-2

Hussen, A. \& Daba, F.B. (2017). Drug Therapy Problems and Their Predictors Among Hypertensive Patients on Follow Up in Dil-Chora Referral Hospital, Dire-Dawa, Ethiopia. International Journal of Pharmaceutical Sciences and Research, $8(6), \quad$ 2712-2719. doi:10.13040/IJPSR.09758232.8(6).2712-19

James, P.A., Oparil, S., Carter, B.L., Cushman, W.C., Dennison-Himmelfarb, C., Handler, J., Lackland, D.T., LeFevre, M.L., MacKenzie, T.D., Ogedegbe, O., Smith, S.C., Svetkey, L.P., Taler, S.J., Townsend, R.R., Wright, J.T., Narva, A.S., \& Ortiz, E. (2014). 2014 evidence-based guideline for the management of high blood pressure in adults: report from the panel members appointed to the Eighth Joint National Committee (JNC 8). JAMA, 311(5), 507-520. doi:10.1001/jama.2013.284427

Li, B., Yang, J., Zhao, F., Zhi, L., Wang, X., Liu, L., Bi, Z., \& Zhao, Y. (2020). Prevalence and impact of cardiovascular metabolic diseases on COVID19 in China. Clinical Research in Cardiology, 
109(5), 531-538. doi:10.1007/s00392-020-016269

Li, X.C., Zhang, J., \& Zhuo, J.L. (2017). The vasoprotective axes of the renin-angiotensin system: physiological relevance and therapeutic implications in cardiovascular, hypertensive and kidney diseases. Pharmacological Research, 125(PtA), 21-38. doi:10.1016/j.phrs.2017.06.005

Lira, C.P., Lolo, W.A., \& Wewengkang, D.S. (2017). Potensi Drug Related Problems (DRPs) Penggunaan Obat Antidiabetes pada Pasien Diabetes Melitus Tipe 2 di Instalasi Rawat Inap Rumah Sakit Kalooran Gmim Amurang. Pharmacon, 64(4), 241-248. doi:10.35799/pha.6.2017.17775

Ministry of Health of the Republic of Indonesia. (2018). Riset Kesehatan Dasar 2018. Jakarta, Indonesia: Health Research and Development Agency, Ministry of Health of the Republic of Indonesia.

Nazilah, K., Rachmawati, E., \& Subagijo, P.B. (2017). Identifikasi Drug Related Problems (DRPs) pada Terapi Diabetes Melitus Tipe 2 di Instalasi Rawat Inap RSD dr. Soebandi Jember Periode Tahun 2015. e-Journal Pustaka Kesehatan, 5(3), 413-419. doi:10.19184/pk.v5i3.5891

Nivya, K., Kiran, V.S.S., Rago, N., Jayaprakash, B., \& Sekhar, M.S. (2015). Systemic review on drug related hospital admissions - A PubMed based search. Saudi Pharmacentical Journal, 23(1), 1-8. doi:10.1016/j.jsps.2013.05.006

Ogbonna, B.O., Ezenduka, C.C., Opara, C.A., \& Ahara, L.G. (2014). Drug Therapy Problems in Patients with Type-2 Diabetes in a Tertiary Hospital in Nigeria. International Journal of Innovative Research \& Development, 3(1), 494 502.

Petrie, J.R., Guzik, T.J., \& Touyz, R.M. (2018). Diabetes, Hypertension, and Cardiovascular Disease: Clinical Insights and Vascular Mechanisms. The Canadian Journal of Cardiology, 34(5), 575584. doi:10.1016/j.cjca.2017.12.005

Ruan, Q., Yang, K., Wang, W., Jiang, L., \& Song, J. (2020). Clinical predictors of mortality due to COVID19 based on an analysis of data of 150 patients from Wuhan, China. Intensive Care Medicine, 46(5), 846-848. doi:10.1007/s00134-020-05991-x
Shareef, J., Fernandes, J., \& Samaga, L.N. (2020). Clinical pharmacist interventions in drug therapy in patients with diabetes mellitus and hypertension in a University Teaching Hospital. International Journal of Pharmacentical Sciences and Research, 6(10), 4424-4432. doi:10.13040/IJPSR.0975-8232.6(10).4424-32

Singh, A.K., Gupta, R., \& Misra, A. (2020). Comorbidities in COVID-19: Outcomes in hypertensive cohort and controversies with renin angiotensin system blockers. Diabetes and Metabolic Syndrome, 14(4), 283-287. doi:10.1016/j.dsx.2020.03.016

Wan, Y., Shang, J., Graham, R., Baric, R.S., \& Li, F. (2020). Receptor Recognition by the Novel Coronavirus from Wuhan: An Analysis Based on Decade-Long Structural Studies of SARS Coronavirus. Journal of Virology, 94(7), e0012720. doi:10.1128/JVI.00127-20

Wu, C., Chen, X., Cai, Y., Xia, J., Zhou, X., Xu, S., Huang, H., Zhang, L., Zhou, X., Du, C., Zhang, Y., Song, J., Wang, S., Chao, Y., Yang, Z., Xu, J., Zhou, X., Chen, D., Xiong, W., Xu, L., Zhou, F., Jiang, J., Bai, C., Zheng, J., \& Song, Y. (2020). Risk Factors Associated with Acute Respiratory Distress Syndrome and Death in Patients with Coronavirus Disease 2019 Pneumonia in Wuhan, China. JAMA Internal Medicine, $\quad 180(7), \quad 1-11$. doi:10.1001/jamainternmed.2020.0994

Yang, X., Yu, Y., Xu, J., Shu, H., Xia, J., Liu, H., Wu, Y., Zhang, L., Yu, Z., Fang, M., Yu, T., Wang, Y., Pan, S., Zou, X., Yuan, S., \& Shang, Y. (2020). Clinical course and outcomes of critically ill patients with SARS-CoV-2 pneumonia in Wuhan, China: a single-centered, retrospective, observational study. The Lancet Respiratory Medicine, 8(5), 475-481. doi:10.1016/S2213-2600(20)30079-5

Yimama, M., Jarso, H., \& Desse, T.A. (2018). Determinants of drug-related problems among ambulatory type 2 diabetes patients with hypertension comorbidity in Southwest Ethiopia: a prospective cross sectional study. BMC Research Notes, 11, 679. doi:10.1186/s13104-018-3785-8

Zazuli, Z., Rohaya, A., \& Adnyana, I.K. (2017). DrugRelated Problems in Type 2 Diabetic Patients with Hypertension: A Prospective Study. Journal of Basic and Clinical Pharmacy, 8, 251-254. 